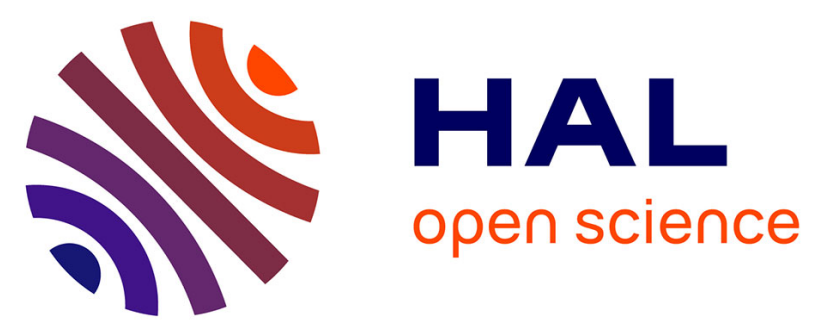

\title{
Chromosomal aberrations in thyroid follicular-cell neoplasia: in the search of novel oncogenes and tumour suppressor genes
}

Horst Zitzelsberger, Gerry Thomas, Kristian Unger

\section{- To cite this version:}

Horst Zitzelsberger, Gerry Thomas, Kristian Unger. Chromosomal aberrations in thyroid follicularcell neoplasia: in the search of novel oncogenes and tumour suppressor genes. Molecular and Cellular Endocrinology, 2010, 321 (1), pp.57. 10.1016/j.mce.2009.11.014 . hal-00582106

\section{HAL Id: hal-00582106 https://hal.science/hal-00582106}

Submitted on 1 Apr 2011

HAL is a multi-disciplinary open access archive for the deposit and dissemination of scientific research documents, whether they are published or not. The documents may come from teaching and research institutions in France or abroad, or from public or private research centers.
L'archive ouverte pluridisciplinaire HAL, est destinée au dépôt et à la diffusion de documents scientifiques de niveau recherche, publiés ou non, émanant des établissements d'enseignement et de recherche français ou étrangers, des laboratoires publics ou privés. 


\section{Accepted Manuscript}

Title: Chromosomal aberrations in thyroid follicular-cell neoplasia: in the search of novel oncogenes and tumour suppressor genes

Authors: Horst Zitzelsberger, Gerry Thomas, Kristian Unger

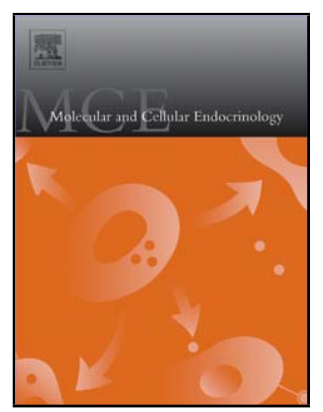

PII:

S0303-7207(09)00579-6

DOI: doi:10.1016/j.mce.2009.11.014

Reference: MCE 7378

To appear in: $\quad$ Molecular and Cellular Endocrinology

Received date: $\quad 30-6-2009$

Revised date: $\quad$ 10-11-2009

Accepted date: $\quad$ 27-11-2009

Please cite this article as: Zitzelsberger, H., Thomas, G., Unger, K., Chromosomal aberrations in thyroid follicular-cell neoplasia: in the search of novel oncogenes and tumour suppressor genes, Molecular and Cellular Endocrinology (2008), doi:10.1016/j.mce.2009.11.014

This is a PDF file of an unedited manuscript that has been accepted for publication. As a service to our customers we are providing this early version of the manuscript. The manuscript will undergo copyediting, typesetting, and review of the resulting proof before it is published in its final form. Please note that during the production process errors may be discovered which could affect the content, and all legal disclaimers that apply to the journal pertain. 
Chromosomal aberrations in thyroid follicular-cell neoplasia: in the search of novel oncogenes and tumour suppressor genes

$$
\text { Horst Zitzelsberger }{ }^{1} \text {, Gerry Thomas }{ }^{2} \text {, Kristian } \text { Unger }^{2}
$$

1 Department of Radiation Cytogenetics, Helmholtz Zentrum München, German Research

Centre for Environmental Health GmbH, Ingolstädter Landstrasse 1, D-85764 Neuherberg,

Germany

${ }^{2}$ Human Cancer Studies Group, Division of Surgery and Cancer-Imperial College London

Hammersmith Hospital

G Block, Du Cane Road, W12 ONN London, United Kingdom

Short Title: Chromosomal changes in thyroid cancer

Corresponding author: Prof. Dr. Horst Zitzelsberger, Helmholtz Center Munich - German

Research Center for Environmental Health $\mathrm{GmbH}$, Department of Radiation Cytogenetics,

Ingolstaedter Landstraße 1, D-85764 Neuherberg, Germany, e-mail:

zitzelsberger@helmholtz-muenchen.de, phone: +49-89-31873421, fax: +49-89-31872873 


\begin{abstract}
Thyroid cancer derived from the follicular cell is characterised by specific gene alterations that are closely linked to the various pathological types comprising papillary, follicular and anaplastic thyroid cancer. However, the correlation between molecular biology and pathology is not absolute, since about $30 \%$ of cases do not harbour the typical gene alterations. This situation, coupled with the demonstration of genetic heterogeneity in thyroid cancer, is a strong motivation for the search of novel gene alterations. Chromosomal aberrations are a good starting point to initiate this search and therefore the current knowledge on chromosomal alterations in thyroid follicular-cell neoplasia is reviewed in this article. An overview on molecular cytogenetic approaches for this strategy is also provided. The identification of novel genetic markers in thyroid cancer will be further improved by integrative approaches combining data from genomic and expression analyses with clinical clinical data. This approach is powerful to identify genetic markers as well as new therapeutic targets in follicular-cell thyroid cancer.
\end{abstract}




\section{Contents}

1. Introduction: Relationship between molecular biology and pathomorphology in thyroid cancer

2. Characterisation of chromosomal changes by molecular cytogenetic approaches

3. Cytogenetic alterations in thyroid cancer

4. Candidate genes in thyroid cancer derived from chromosomal aberrations

5. Future directions: An integrative biological approach within the GENRISK-T project

6. Conclusion

Acknowledgements

References 


\section{Introduction: Relationship between molecular biology and pathomorphology in thyroid cancer}

Differentiated thyroid cancers derived from the follicular cell can be divided into two main types, papillary and follicular cancers. Papillary thyroid carcinoma (PTC) arises de novo from the follicular epithelial cell and is typically composed of papillary structures. Follicular cancers $(F C)$ are morphologically similar to follicular adenomas, which are benign lesions. Evidence of invasion through the capsule into veins or extra-thyroid tissues distinguishes follicular carcinoma from follicular adenoma. Diagnosis is made on a number of pathomorphological features characteristic for PTCs (e.g. grooved pale nuclei that frequently show intranuclear cytoplasmic inclusions and psammoma bodies which are calcified structures found within the tumours) that are lacking in follicular tumours. The diagnosis of PTC depends on the presence of a number of these features, but not all have to be present for a diagnosis of papillary cancer to be made (Al-Brahim and Asa 2006).

In addition to the two main types of cancer derived from the follicular cells, there are a number of subtypes of both PTCs and FCs. These are named on the dominant structural component. Beside the above mentioned classic PTC, the most commonly found in adults is the follicular variant of PTC which is composed of follicular structures but has the nuclear features and psammoma bodies that are typical for papillary cancer. The solid or solid follicular variant of PTC is composed of solid sheets of cells with or without a follicular component. The latter variant shows variable nuclear features but does contain psammoma bodies. There are other, rarer subtypes of PTCs but these will not be further discussed in this review. FCs are subdivided on the basis of their follicular size - micro, normo or macrofollicular, and where there is a lack of follicular lumina and the morphology appears more solid, trabecular. For an excellent comprehensive review of follicular cell neoplasia, rather than just thyroid cancer, the reader is referred to Kondo et al. (2006).

The broad division made on pathomorphological grounds between papillary and follicular cancers is further supported by molecular evidence. PTCs are associated with rearrangements of the Ret and Trk oncogenes and more commonly in adult PTCs, mutations of the Braf oncogene. The region coding the Ret tyrosine kinase has been shown to fuse with a number of different partners. The Ret oncogene is not expressed in follicular epithelial cells, but fusion of the tyrosine kinase domain to genes with a promoter that is 
active in the follicular cells and permits Ret signalling through the MAPkinase pathway (Nikiforov 2002). This so-called RET/PTC rearrangement is formed by fusion of the $3^{\prime}$ portion of Ret with different partner genes. The commonest rearrangements, RET/PTC1 and RET/PTC3, involve paracentric inversion on chromosome 10 and are termed PTC1 and PTC3since both partner genes, $\mathrm{H} 4$ and Ncoa4 are also located on chromosome 10. Initial studies reported that there was a higher than expected frequency of Ret rearrangement in PTC arising in the population exposed to radiation from the Chernobyl accident, suggesting some Ret rearrangements might be regarded as a marker for radiation exposure (Fugazzola, et al. 1995; Klugbauer, et al. 1995). More recent papers have suggested that there is not a link between radiation exposure and Ret rearrangements since frequent RET/PTC rearrangements have also been observed in sporadic papillary carcinomas from children and young adults with a prevalence of 40 to $70 \%$ of cases (Tuttle, et al. 2008). These findings may therefore reflect more the association between the solid morphological subtype with RET/PTC3 rearrangement and the age of the patient at diagnosis, rather than the aetiology of the tumour (Nikiforova, et al. 2004; Thomas, et al. 1999).

However, in contrast to the post-Chernobyl tumours radiation-associated thyroid tumours either as a result of exposure to radiation for therapeutic puposes (Bounacer, et al. 1997) or developed in the atomic bomb survivors (Hamatani, et al. 2008)exhibited most frequently RET/PTC1 rearrangements. Altogether, these findings indicate that Ret rearrangements are not induced in each case by ionising radiation and therefore make RET/PTC as a radiationspecific marker in papillary thyroid carcinomas questionable, at the very least.

It is important to remember that the correlation between molecular biology and pathology is not absolute: in all of the series published so far, a substantial proportion $(30 \%-50 \%)$ of papillary cancers do not harbour rearrangements of the Ret gene at all. A variety of different techniques have been used to assess the frequency of Ret rearrangements and, although this may explain the variation in frequency of Ret rearrangements among studies (Zhu, et al. 2003), a large proportion of papillary carcinomas still remain that are negative for Ret rearrangements and for which the alternative molecular pathways need to be identified. Moreover, a few studies have demonstrated Ret rearrangements in benign tumours associated with radiation exposure (Bounacer et al. 1997; Elisei, et al. 2001; Sadetzki, et al. 2004) and those without radiation history (Rhoden, et al. 2006); however, other studies have failed to substantiate these findings (Thomas et al. 1999), adding further uncertainty to 
the specific association of Ret rearrangement with papillary thyroid cancer. A recent paper by Port et al. (2007) has suggested a radiation signature consisting of seven genes which are differentially expressed in post-Chernobyl and sporadic PTC. However, caution is urged in the interpretation of this paper because the radiation-associated group was substantially younger than the control group and of a different ethnic origin, and detailed pathological information is lacking. The signature could therefore relate to variables inherent in the design of the study rather than specifically to radiation exposure.

In contrast to the association between the young onset, solid morphology of PTCS associated with Ret rearrangement, mutations in Braf show a different association with morphology. In the case of Braf the association is with older age at diagnosis and with a more classical PTC morphology. The frequency for Braf mutation varies in a number of studies from 36\% to 69\% in adult PTC (Cohen, et al. 2003; Kimura, et al. 2003; Powell, et al. 2005). The frequency in post-Chernobyl cases (aged under 18 years at operation) is much lower: less than 10\% (Nikiforova et al. 2004); and does not appear to be significantly different from that observed in sporadic cases of childhood thyroid papillary carcinoma (Lima, et al. 2004). This finding is perhaps not surprising as Braf and Ret oncogenic alterations appear to be virtually mutually exclusive in the series published thus far. However, it is clear that all cases that are negative for Braf in young onset papillary cancer are not necessarily positive for Ret rearrangement, and that there are as yet unidentified oncogenic changes in these tumours. A novel rearrangement involving inversion of chromosome 7, resulting in fusion of part of the Braf gene with the Akap9 gene has also been described in three papillary carcinomas from young children in Belarus (Ciampi, et al. 2005). However, further studies in age matched cases will be needed to establish whether this is a radiation-specific event or is related to age at diagnosis.

In contrast, FCs show a spectrum of DNA alterations that are different from PTCs. In particular, mutations of the $\mathrm{H}$-ras and $\mathrm{N}$-ras genes have been observed in FCs and follicular adenomas, but rarely in PTCs (Basolo, et al. 2000; Lemoine, et al. 1989; Manenti, et al. 1994; Namba, et al. 1990). The correct pathological assessment of the tumour is important in this distinction, as follicular variant PTCs can be misdiagnosed as FCs in some circumstances. In addition, the variation in frequency of Ras gene mutation in different series may be related to the differing techniques used in these older studies. A second common oncogenic alteration associated with FC and follicular adenoma is the translocation of peroxisome 
proliferator activated receptor $\gamma$-Ppar $\gamma$ - to the Pax8 gene promoter (Marques, et al. 2002). As observed with PTC, Ras gene mutation and Ppary/Pax8 are mutually exclusive in FC, suggesting that their major function in FC may be through the same pathway. Interestingly, rearrangements of Ppary correlated with younger age at diagnosis and Ras mutation with older age at diagnosis, suggesting that as with PTC, age at onset plays a major role in the molecular signature of the tumour (Nikiforova, et al. 2003). There are a number of other differences in gene expression that are associated with follicular cell neoplasia, but as this review focuses largely on alterations in DNA copy number, these are not reviewed here.

Undifferentiated thyroid cancer is termed Anaplastic Thyroid Carcinoma (ATC), and may derive from PTC, FC or a tumour derived from the $C$ cell component of the thyroid, Medullary Thyroid Carcinoma (MTC, Williams 1966). The oncogenic changes found in ATC therefore reflect not only the changes related to the type of differentiated cancer from which it has evolved, but also new changes associated with its loss of differentiated thyroid cell function.

In summary, the various pathological types of thyroid cancer are closely linked to the alteration in DNA sequence and gene expression, and proper interpretation of molecular biological results should be accompanied by detailed pathological information to permit the researcher to compare results between studies. It is perhaps unsurprising that pathomorphology is so tightly linked to molecular biology - after all the morphology of a tumour is a consequence of the expression of the genes within it. 


\section{Characterisation of chromosomal changes by molecular cytogenetic approaches}

Genomic rearrangements are common alterations in haematological malignancies and solid human cancers that often represent recurrent and therefore characteristic alterations for particular tumour types (Mitelman 2000; Teixeira 2006, Mitelman database of chromosome aberrations in cancer (2009), http://cgap.nci.nih.gov/chromosomes/Mitelman). A de novo characterisation of whole genomic alterations can be achieved by molecular cytogenetic approaches such as comparative genomic hybridisation (CGH, Kallioniemi et al. 1993) and chromosome-specific FISH karyotyping (Schrock, et al. 1997; Speicher, et al. 1996; Szuhai, et al. 2000). This enables the identification of genomic copy number alterations (CNA) and structural chromosomal aberrations. A strong advantage of these techniques is that they do not require a prior knowledge of the alterations present in contrast to single- or multiplexprobe FISH techniques which target one or more genomic loci at the same time and can only be applied if genomic alterations such as copy number changes, inter- and intrachromosomal translocations or inversions are known.

For many decades G-banding of metaphases and subsequent karyotyping was the only approach to detect chromosomal changes. The application was limited by the requirement of an expert with a high level of expertise in cytogenetics, a need for high quality metaphase spreads and relatively low resolution which made smaller alterations undetectable. A vast improvement was attained by the invention of chromosome-specific FISH painting probes that label each chromosome with a specific colour or colour-mix. This makes inter chromosomal rearrangements identifiable by colour junctions of the FISH-painted rearranged chromosome. Three methods have been published for chromosome-specific fluorescence labelling - M-FISH (Speicher et al. 1996), spectral karyotyping (Schrock et al. 1997) and COBRA-FISH (Szuhai et al. 2000) which mainly differ in the way of probe generation, image acquisition and computational classification of chromosomes. The best possible resolution that can be achieved with these techniques is about $2 \mathrm{Mb}$ (Speicher et al. 1996) and requires optimized metaphase spreads preparations.

A technique specially designed for scanning whole tumour genomes for genomic copy aberrations such as gains (duplications, amplifications) and losses (hemizygous -and homozygous deletions) is CGH (Kallioniemi et al. 1993). It uses differentially fluorescencelabelled and fragmented reference and tumour DNA which is in situ co-hybridised to normal 
metaphase spreads. During hybridisation fragments of reference and test DNA compete for complementary binding-sites presented by the normal metaphase chromosomes. The relative amounts of tumour DNA and reference DNA which bind a particular region on the metaphase chromosomes reflect copy number of the according region in the tumour genome. Gained regions are reflected by a tumour to reference fluorescence ratio larger than one and losses by ratios smaller than one. Since conventional CGH requires metaphase spreads the detection of CNA is typically limited to 10-20 Mb (Parente, et al. 1997).

The limitation of the low resolution of metaphase CGH has been overcome by replacing metaphases with DNA microarrays as hybridisation target (Solinas-Toldo, et al. 1997) and is appropriately named Array CGH (Figure 1). In addition to higher sensitivity, this technical improvement has several advantages such as higher potential throughput, and less amount of time from sample to result due to development in computer technology and bioinformatics which is needed to process the type of data produced. Moreover, an expertise of a cytogeneticist is not an absolute requirement. The first generation of DNA arrays for array CGH used large-insert clones such as BACs and PACs (Fiegler, et al. 2003; Pinkel, et al. 1998) giving a detection limit of $1 \mathrm{Mb}$. Even though resolution of BAC arrays using a higher number of BAC clones was steadily increased and the advent of arrays using oligonucleotides as hybridisation targets (Carvalho, et al. 2004) has resulted in complete coverage of the genome with almost no gaps (Fiegler, et al. 2006), a majority of published array $\mathrm{CGH}$ studies used $1 \mathrm{Mb} B A C$ array $\mathrm{CGH}$. This may be due to the fact that BAC arrays are relatively cheap, robust and applicable to DNA from formalin-fixed paraffin embedded (FFPE) tissue (van Beers, et al. 2006).

Single or multicolour FISH approaches that detect known gene targets can be used on either metaphase preparations or interphase cells of archived tissue samples in order to identify numerical or structural alterations at a single cell level. The labelled DNA from large-insert clones is typically used as a DNA probe for hybridisation on metaphase spreads or on sections from FFPE tissue blocks.

Hybridisation on metaphase spreads enables the researcher to narrow down the position of chromosomal breakpoints of translocations. For this, a series of probes is selected which bind within the region of the suspected chromosomal breakpoint. Subsequent hybridisation identifies either breakpoint-spanning or - flanking FISH probes whose mapping information can be used for the identification of candidate genes from gene databases. The clones 
additionally can be used as translocation-specific probes for interphase-FISH on tissue samples. This strategy was used, for example, in human PTC to investigate the frequency and distribution of Ret/PTC rearrangements (Unger, et al. 2004). Moreover, FISH probes can be generated mapping candidate regions of genomic gains or losses in order to confirm results from array CGH studies. Such alteration-specific FISH probes are also a valuable tool to verify on large tumour cohorts (tissue microarrays) and to validate results from cell lines in human clinical tissue collections.

The recently developed next generation sequencing approaches become available to a growing community of researchers and have the potential to give answers to various biological questions by using genomic DNA or total RNA extracted from human tissue or blood. Its main limitation is still the exorbitant costs for running and maintenance of equipment and for carrying out the experiments itself. A review by Mardis (2008) gives an excellent overview about next generation sequencing and its potential in modern molecular biology. Bashir et al. (2008) describe the potential and limitation of the characterisation of chromosomal rearrangements using next generation sequencing. In particular, next generation sequencing is a promising approach for the detection of chromosomal rearrangements in tumours because it is potentially applicable to DNA from both archived and fresh tumours. 


\section{Cytogenetic alterations in thyroid follicular-cell neoplasia}

The tumourigenesis of human solid tumours is driven by the aberrant function of genes involved in cell proliferation, apoptosis, genome stability and angiogenesis (Hanahan and Weinberg 2000). Many different factors such as genome copy number changes, structural aberrations, polymorphisms, point mutations and epigenetic modifications can result in an aberrant gene function. Thereby the selection of these mechanisms varies, e.g. inactiviation of tumour suppressor genes can be caused by deletion, mutation or gene methylation whilst activation of proto-oncogenes can be achieved by gene rearrangements or gains of chromosomal regions. Thus, chromosomal aberrations are important features of solid tumours with distinctive impact on the function of cancer genes.

This also holds for thyroid follicular-cell neoplasia. The cytogenetic features of these tumours mainly depend on the type of thyroid cancer and partly allow distinguishing papillary, follicular and anaplastic cancers by characteristic genomic alteration patterns. Similar to other solid tumours, much more data on DNA copy number changes is published compared with the amount of data available on structural chromosome aberrations. This is due to the technical fact that identification of structural rearrangements only is feasible from primary short-term cultures but not from archived tumour tissues whilst genomic copy number analysis can be well done from both.

In papillary thyroid carcinomas (PTC), 10q rearrangements with breakpoints at $10 \mathrm{q} 11.2$ leading to an activation of the Ret oncogene (Santoro, et al. 1992) were frequently found (Pierotti, et al. 1992). Especially in radiation-associated PTC, several translocations have been reported which led to novel Ret activating fusion proteins (Corvi, et al. 2000; Fugazzola, et al. 1996; Klugbauer, et al. 1998; Klugbauer and Rabes 1999; Nakata, et al. 1999; Pierotti, et al. 1996; Salassidis, et al. 2000, reviewed by Santoro et al. (2006)). Chromosomal translocations and inversions with breakpoints at 1q22 were shown to activate another receptor tyrosine kinase, Trk and, just like Ret, was only seen in PTC (Bongarzone, et al. 1996; Said, et al. 1994).

Since only a subgroup of PTC showed the above mentioned aberrations other studies which aimed to identify additional chromosomal abnormalities reported chromosomal breakpoints on 1p32-36, 1p11-13, 3p25-26 and 7q32-36 in PTC after conventional karyotyping (Roque, et al. 2001). In primary cultures of radiation-associated thyroid tumours, novel breakpoints on chromosomes 4q, 5q, 6p, 12q, 13q and 14q were described by comprehensive analysis using 
conventional and spectral karyotyping (Zitzelsberger, et al. 1999). Spectral karyotyping also uncovered complex rearrangements in some tumours (Lu, et al. 2009; Weier, et al. 2006)that have been investigated further by a BAC-FISH approach in order to delineate chromosomal breakpoints. In Figure 2 an example for fine-mapping of chromosomal breakpoints by FISH is shown for a case of a post-Chernobyl PTC.

Much more data on DNA copy number changes in PTC are available from which Table 1 summarizes the most commonly cited in the published literature. In a conventional CGH study on radiation-associated PTC the most frequent copy number changes reported were on chromosomes 2, 7q11.2-21, 13q21-22, 16, 20, 21 and 22 (Richter, et al. 2004) which was in accordance with the chromosome 22 changes reported in other studies (Hemmer, et al. 1999; Singh, et al. 2000) linking its presence to a widely invasive subtype of PTC. In addition, Kitamura et al. (2000) described an association of allelic losses of $1 q, 4 p, 9$ and $16 q$ with survival in PTC. More recent studies using array-CGH of specimen enriched for tumour cells by microdissection showed a more common appearance of copy number changes in PTC (Finn, et al. 2007; Unger, et al. 2008). In these studies, recurrent aberrations were reported which are in accordance with previous CGH studies and which discriminate RET/PTC-positive and -negative tumours (Unger et al. 2008) or are typical for wildtype Ret or Braf tumours (Finn et al. 2007). In focal papillary carcinoma with changes in follicular-patterned thyroid nodules trisomy 17 was identified which potentially reflects a specific marker of this subset of thyroid lesions (Frau, et al. 2008). All these data on DNA copy number changes and structural chromosome aberrations in PTC suggest the existence of additional "driver" aberrations beside the known gene alterations of the MAPK pathway (Ret, Braf).

Compared to PTC chromosomal changes are much more frequent in follicular and anaplastic thyroid carcinomas. In follicular thyroid carcinomas (FTC), cytogenetic abnormalities of chromosome 3 are characteristic changes (Herrmann, et al. 1991) and losses at $3 p$ and of 3p25-pter in particular are the most common chromosomal aberrations in FTC (Roque, et al. 1993). Further CGH analysis of FTC defined three common regions of losses at 3p25-pter, $3 p 21$, and 3q29-qter suggesting the involvement of more than one genomic region of chromosome 3 in follicular carcinogenesis. It is known that translocations with breakpoints at chromosome 3p25 lead to rearrangements of the gene Ppary (Kroll, et al. 2000). Other frequent copy number changes described in FTC are deletions of $1 p, 6 p / q, 8 p / q, 9 p, 11 q$, 13q, 18q, and 22q (Hemmer et al. 1999; Hemmer, et al. 1998; Roque, et al. 2003). In 
addition, loss of chromosome 22 was reported to be associated with an invasive phenotype in FTC. This finding supports the idea that an aggressive phenotype in thyroid cancer is driven by the same genetic changes irrespective of the tumour type since chromosome 22 changes were also linked to a widely invasive phenotype in PTC. The oncocytic subtype of FTC commonly shows multiple numerical chromosome changes including polysomy of chromosome 7 (Dettori, et al. 2003) and a new possible mechanism of Braf activation (Ciampi et al. 2005) by gain of copy number. Braf gene reduplication has been shown to be present in these tumours, suggesting that activation of the MAPkinase pathway is also critical in thyroid follicular cell tumourigenesis although Braf mutations or RET/PTC rearrangements are absent (Musholt, et al. 2008).

Anaplastic thyroid carcinoma (ATC) is a rare but particularly aggressive tumour (Chiacchio, et al. 2008). Surprisingly, the extent of DNA copy number changes does not directly correlate with the aggressiveness of tumours, when different histological types are compared. This is supported by the finding that only few ATC with an abnormal karyotype have been reported (Jenkins, et al. 1990; Mark, et al. 1987). More recently, advanced molecular cytogenetic approaches such as spectral karyotyping enabled the detection of numerous structural aberrations in ATC cell lines revealing chromosomal breakpoints at $1 p 36$ and 17q24-25 which are novel in ATC as well as breakpoints at 3p21-22 and 15q26 which were described for well-differentiated thyroid cancers (Lee, et al. 2007). In contrast to this limited knowledge on structural chromosome aberrations in ATC, copy number changes were reported to greater extent. Recurrent chromosomal imbalances are gains of $1 q$ and $20 q$ which both were described in cell lines and in primary tumours (Lee et al. 2007; Miura, et al. 2003). In another study gains and losses on chromosomes $8 p$ and $8 q$ as well as gains on $5 p$ were regarded as typical changes which were rarely found in well-differentiated thyroid cancers (Wilkens, et al. 2000). Overall, an increase in aberration complexity was reported for the progression from well-differentiated to poorly differentiated and anaplastic carcinomas. In contrast to Wilkens et al. (2000) chromosomal abnormalities of 5p15, 5q11$13,19 p / q$ (gains) and of $8 p$ (loss) were regarded as common to all thyroid cancer types, whereas gains on 1p34-36, 6p21, 9q34, 17q25 and 20q as well as losses of 1p11-31, 2q32$33,4 q 11-13,6 q 21$ and 13q21-31 were found only in poorly differentiated tumours and ATC (Wreesmann, et al. 2002). In this study, recurrent gains of 3p13-14 and 11q13 and loss of 5q11-31 were reported as unique markers for ATC. Although there are coincidental findings 
in these reports such as chromosome 20 abnormalities, a common issue with all of the studies on ATC seems to be the low number of cases studied (range: seven to 28 cases per study) which makes it difficult to identify specific recurrent aberrations. 


\section{New candidate genes in thyroid cancer derived from chromosomal aberrations}

As mentioned above a number of gene alterations are known in thyroid follicular-cell neoplasms. However, the reported gene alterations do not occur in all cases of a particular thyroid cancer type and, moreover, frequently show a heterogeneous distribution of alterations within the tumour (Ciampi and Nikiforov 2007; Unger et al. 2004; Unger, et al. 2006). This was a strong motivation to search for gene alterations in thyroid follicular-cell neoplasia which interact with the known genetic changes or act as alternative drivers of tumourigenesis.

To address this question many studies used gene expression approaches, some of them combined with LOH analysis, for the detection of novel tumour suppressors or oncogenes. In one of these studies this strategy resulted in the identification of the noncoding RNA gene, Nama, which is downregulated in PTC positive for B-raf mutation and associated with growth arrest (Yoon, et al. 2007). Another novel candidate gene associated with ATC is Plk1 (Polo-like Kinase 1) which was identified by expression microarray screening. It represents a serine/threonine kinase playing an important role in a number of G2- and M-phase-related events (Salvatore, et al. 2007). It is of special interest that Plk1 was subsequently shown to represent a potential therapeutic target in ATC (Nappi, et al. 2009). In FTC overexpression of Akt1 and Akt2 as well as increased levels of total AKT activity has been reported (Ringel, et al. 2001). Other components of this pathway such as Pi3kca have been shown to be gained in copy number or mutated in both, FTC (Wu, et al. 2005) and ATC (Garcia-Rostan, et al. 2005). However, Akt activation which is linked to tumour progression (Guarino, et al. 2005; Vitagliano, et al. 2004) also plays a role in PTC tumourigenesis where RET/PTC rearrangements are associated with the expression of genes downstream of PI3K (Giordano, et al. 2005).

Another strategy to discover candidate genes involved in thyroid tumourigenesis is the usage of genomic approaches with chromosomal aberrations as the starting point. There are different molecular cytogenetic approaches to delineate chromosomal breakpoints. One BAC-FISH-based approach allows cloning of aberrations by using pools of uniformly labelled BAC clones covering a relatively large candidate region in the first place followed by a hybridisation with individual BAC probes labelled with individual dyes (Lu et al. 2009). This approach has been applied to a primary culture of post-Chernobyl thyroid tumours PTC in order to characterise chromosomal alterations on chromosome 9 (Weier et al. 2006). In 
another study, the Thada gene, a putative death receptor-interacting protein, was identified with the same approach on chromosome 2p21 of a thyroid adenoma cell line (Rippe, et al. 2003). Fig. 2 illustrates FISH mapping of chromosomal breakpoints of an insertion of qterminal parts of chromosome 7 into chromosome 12 performed on the primary culture of a post-Chernobyl PTC. For this study YAC clones (CEPH library) and BAC clones (RPCI library) were used in FISH hybridisations. The breakpoint-spanning hybridisation probes enabled the identification of the candidate genes Ppp1r9a, Pon1, Pon2, Pon3, Asb4, Pdk4, Dynclil on chromosome 7 and Spryd3, Igbp6, Soat2, Acat2, Csad, Pcap, Znf740, Itgb7, Rarg on chromosome 12 (personal communication with K. Unger).

Another strategy to narrow down chromosomal alterations is the use of array-based approaches. Depending on the resolution of the arrays used these approaches often require subsequent BAC-FISH fine-mapping of chromosomal regions or breakpoints. There are only few array CGH studies on DNA copy number changes in thyroid follicular cell neoplasia and only three in PTC (Finn et al. 2007; Rodrigues, et al. 2007; Unger et al. 2008). Another study from Lee et al. (2008) focused on ATC whilst Chen et al. (1998) showed data on a mixed collection of tumours (PTC, FTC, ATC). For PTC a variety of novel candidate genes was reported from the most recurrent copy number changes. Finn et al. (2007) described amplified Tp73 (1p36.33), Snrpn (15q12) and Pdgfb (22q13.1) to be present in wild-type Braf tumours only. In contrast, Unger et al. (2008) showed different copy number alterations for RET/PTC-positive and-negative PTC and reported a panel of candidate genes that are derived from these discriminating regions of copy number changes. For the commonly altered regions they described Rmi1, Gas1, Shc3, Syk, FancC, Ptch1, Klf6, Net1, Rsu1, Nrp1, Pard3, Ret, Anxa7, Slit1, and Timp3 as tumour-related candidate genes that may be additionally involved in tumourigenesis. The discrepancy of the reported candidate genes are presumably due to the fact that different tumour cohorts were investigated in the two studies (childhood vs. adult patients, differences in the genetic background for B-raf muations and Ret rearrangements). The only study on copy number in ATC so far demonstrated a deletion of 9p21.3 which encodes for cyclin-dependent kinase 2a/p16 (Cdkn2a) and gains of the genes Ubch10 (20q13.12) and Cond1 (11q13). The alterations represent the most frequent changes in this series of 27 ATC (Lee et al., 2008). Most of the studies using array CGH validate their findings in an exemplarily manner for selected candidate genes by BAC-FISH. Since array CGH is a genome-wide screening approach which 
comes along with the possibility of false-positive findings cross-confirmation of results is indispensable. 


\section{Future directions: integrative biology performed in the GENRISK-T project}

Although genomic alterations are useful starting points for an elucidation of molecular mechanisms in thyroid follicular-cell neoplasias the question remains which changes are crucial in terms of leading to aberrant gene expressions and tumour phenotypes. To address this key question an integrative statistical approach of data analysis is necessary combining data on genomic and expression changes with clinical data on tumour phenotypes and clinical data of patients. Such an integrative analysis is demonstrated in Fig. 3 and is pursued in an EC-coordinated consortium called GENRISK-T which focuses research at different molecular levels on an age- and histology-matched cohort of post-Chernobyl PTC from the Chernobyl Tissue Bank (CTB).

Large scale collections of biological samples of various formats from human thyroid cancer such as those available from the Chernobyl Tissue Bank (www.chernobyltissuebank.com) are changing the way in which research can be done. In the past researchers have had to rely on small scale collections from usually their own institution, and because of financial constraints on research budgets, have been able to analyse the samples with only one molecular biological technique. Research Tissue Banks open up the prospect of different groups of researchers being able to have access to material in different formats, the molecular analyses of which complement each other. The Genrisk-T project provides a paradigm for this type of project. The aim is to identify genes in thyroid cancer, with specific relevance to radiation induced thyroid cancer and to develop animal models that can be used to investigate the risks of exposure to low dose radiation. The human component of the project focuses on an integrated biology approach using a case-by-case design matched on age, sex and residency, but differing for exposure to radioiodine. Data on genomic copy number, genotype, gene expression, miRNA, Ret rearrangement, pathology and clinical data from these cases are collated in a central source and going to be analysed using an integrative approach in order to achieve highest efficiency and most possible output. One of the biggest hurdles in the correlation analysis of large-scale datasets is the decrease of statistical power due to correction of $p$-values for multiple testing (Hochberg and Benjamini 1990). P-values by nature are normal distributed and consequently a large number ( $>100)$ of statistical tests due to a high number of data points per dataset is accompanied by falsepositive results (type I errors). In studies with smaller numbers of cases this shrinks the statistical power in such an extent that it is almost impossible to detect important 
associations. Most often the statistical power of a study cannot be improved by increasing the number of studied cases. An alternative solution to this problem is reduction of data complexity by eliminating those data points of the dataset which cannot be expected to correlate with any of the investigated features. For genomic copy number data this can be done by including only those genomic regions in the analysis which show copy number alterations in a sensible proportion of cases (van de Wiel and van Wieringen 2007). In the described setting in which data from the same samples are available from various platforms even more options of reducing data complexity are possible. Thus further complexity reduction can be achieved by taking only data points into account which correlate with the findings from one or more of the other platforms. This could be genomic copy number data correlating with mRNA or miRNA expression, mRNA expression correlating with SNP patterns or miRNA expression associated with genomic copy number alterations (van de Wiel and van Wieringen 2007; van Wieringen and van de Wiel 2009). Another way of substantially reducing data complexity is looking at genes which participate in a particular pathway only or collections of candidate genes gathered from own or published results. After reduction of data complexity, results are correlated with pathomorphology, molecular biological status such as B-raf mutation status or Ret expression status.

As an extension to this strategy the effect of SNPs on gene expression and miRNA expression will also be examined, as this has already been shown to be important in thyroid cancer (Jazdzewski, et al. 2008). The results are predicted to identify pathways that are important in thyroid carcinogenesis and provide data for future functional studies on novel genes in thyroid cancer. This project offers a new paradigm for cancer research in general, and highlights the future research possibilities of access to large numbers of quality assured biosamples which will become available to the research community as biobanking activity increases. 


\section{Conclusion}

It is evident from a large number of studies on thyroid follicular-cell neoplasia that chromosomal aberrations are good starting points for the search of novel cancer genes involved in tumourigenesis. Advanced molecular cytogenetic techniques facilitate this effort. It has been shown in this review that an integrative approach combining data from this genomic analysis with expression and clinical data is straight forward to identify genetic markers that may represent novel therapeutic targets in thyroid cancer. 


\section{Acknowledgements}

The work was financially supported in part by EC grant FP6-36495. 


\section{References}

Al-Brahim N \& Asa SL 2006 Papillary thyroid carcinoma: an overview. Arch Pathol Lab Med $1301057-1062$.

Bashir A, Volik S, Collins C, Bafna V \& Raphael BJ 2008 Evaluation of paired-end sequencing strategies for detection of genome rearrangements in cancer. PLoS Comput Biol 4 e1000051.

Basolo F, Pisaturo F, Pollina LE, Fontanini G, Elisei R, Molinaro E, lacconi P, Miccoli P \& Pacini F $2000 \mathrm{~N}$-ras mutation in poorly differentiated thyroid carcinomas: correlation with bone metastases and inverse correlation to thyroglobulin expression. Thyroid $\mathbf{1 0}$ 19-23.

Bongarzone I, Fugazzola L, Vigneri P, Mariani L, Mondellini P, Pacini F, Basolo F, Pinchera A, Pilotti S \& Pierotti MA 1996 Age-related activation of the tyrosine kinase receptor protooncogenes RET and NTRK1 in papillary thyroid carcinoma. J Clin Endocrinol Metab 81 2006-2009.

Bounacer A, Wicker R, Caillou B, Cailleux AF, Sarasin A, Schlumberger M \& Suarez HG 1997 High prevalence of activating ret proto-oncogene rearrangements, in thyroid tumors from patients who had received external radiation. Oncogene 15 12631273.

Carvalho B, Ouwerkerk E, Meijer GA \& Ylstra B 2004 High resolution microarray comparative genomic hybridisation analysis using spotted oligonucleotides. J Clin Pathol 57 644646.

Chen X, Knauf JA, Gonsky R, Wang M, Lai EH, Chissoe S, Fagin JA \& Korenberg JR 1998 From amplification to gene in thyroid cancer: a high-resolution mapped bacterialartificial-chromosome resource for cancer chromosome aberrations guides gene discovery after comparative genome hybridization. Am J Hum Genet 63 625-637. 
Chiacchio S, Lorenzoni A, Boni G, Rubello D, Elisei R \& Mariani G 2008 Anaplastic thyroid cancer: prevalence, diagnosis and treatment. Minerva Endocrinol 33 341-357.

Ciampi R, Knauf JA, Kerler R, Gandhi M, Zhu Z, Nikiforova MN, Rabes HM, Fagin JA \& Nikiforov YE 2005 Oncogenic AKAP9-BRAF fusion is a novel mechanism of MAPK pathway activation in thyroid cancer. J Clin Invest 115 94-101.

Ciampi R \& Nikiforov YE 2007 RET/PTC rearrangements and BRAF mutations in thyroid tumorigenesis. Endocrinology 148 936-941.

Cohen Y, Xing M, Mambo E, Guo Z, Wu G, Trink B, Beller U, Westra WH, Ladenson PW \& Sidransky D 2003 BRAF mutation in papillary thyroid carcinoma. J Natl Cancer Inst 95 625-627.

Corvi R, Berger N, Balczon R \& Romeo G 2000 RET/PCM-1: a novel fusion gene in papillary thyroid carcinoma. Oncogene 19 4236-4242.

Dettori T, Frau DV, Lai ML, Mariotti S, Uccheddu A, Daniele GM, Tallini G, Faa G \& Vanni R 2003 Aneuploidy in oncocytic lesions of the thyroid gland: diffuse accumulation of mitochondria within the cell is associated with trisomy 7 and progressive numerical chromosomal alterations. Genes Chromosomes Cancer 38 22-31.

Elisei R, Romei C, Vorontsova T, Cosci B, Veremeychik V, Kuchinskaya E, Basolo F, Demidchik EP, Miccoli P, Pinchera A, et al. 2001 RET/PTC rearrangements in thyroid nodules: studies in irradiated and not irradiated, malignant and benign thyroid lesions in children and adults. J Clin Endocrinol Metab 86 3211-3216.

Fiegler H, Carr P, Douglas EJ, Burford DC, Hunt S, Scott CE, Smith J, Vetrie D, Gorman P, Tomlinson IP, et al. 2003 DNA microarrays for comparative genomic hybridization based on DOP-PCR amplification of BAC and PAC clones. Genes Chromosomes Cancer 36 361-374. 
Fiegler H, Redon R, Andrews D, Scott C, Andrews R, Carder C, Clark R, Dovey O, Ellis P, Feuk L, et al. 2006 Accurate and reliable high-throughput detection of copy number variation in the human genome. Genome Res 16 1566-1574.

Finn S, Smyth P, O'Regan E, Cahill S, Toner M, Timon C, Flavin R, O'Leary J \& Sheils O 2007 Low-level genomic instability is a feature of papillary thyroid carcinoma: an array comparative genomic hybridization study of laser capture microdissected papillary thyroid carcinoma tumors and clonal cell lines. Arch Pathol Lab Med 131 65-73.

Frau DV, Lai ML, Caria P, Dettori T, Coni P, Faa G, Morandi L, Tallini G \& Vanni R 2008 Trisomy 17 as a marker for a subset of noninvasive thyroid nodules with focal features of papillary carcinoma: cytogenetic and molecular analysis of 62 cases and correlation with histological findings. J Clin Endocrinol Metab 93 177-181.

Fugazzola L, Pierotti MA, Vigano E, Pacini F, Vorontsova TV \& Bongarzone I 1996 Molecular and biochemical analysis of RET/PTC4, a novel oncogenic rearrangement between RET and ELE1 genes, in a post-Chernobyl papillary thyroid cancer. Oncogene 13 1093-1097.

Fugazzola L, Pilotti S, Pinchera A, Vorontsova TV, Mondellini P, Bongarzone I, Greco A, Astakhova L, Butti MG, Demidchik EP, et al. 1995 Oncogenic rearrangements of the RET proto-oncogene in papillary thyroid carcinomas from children exposed to the Chernobyl nuclear accident. Cancer Res 55 5617-5620.

Garcia-Rostan G, Costa AM, Pereira-Castro I, Salvatore G, Hernandez R, Hermsem MJ, Herrero A, Fusco A, Cameselle-Teijeiro J \& Santoro M 2005 Mutation of the PIK3CA gene in anaplastic thyroid cancer. Cancer Res 65 10199-10207.

Giordano TJ, Kuick R, Thomas DG, Misek DE, Vinco M, Sanders D, Zhu Z, Ciampi R, Roh M, Shedden K, et al. 2005 Molecular classification of papillary thyroid carcinoma: distinct BRAF, RAS, and RET/PTC mutation-specific gene expression profiles discovered by DNA microarray analysis. Oncogene 24 6646-6656. 
Guarino V, Faviana P, Salvatore G, Castellone MD, Cirafici AM, De Falco V, Celetti A, Giannini R, Basolo F, Melillo RM, et al. 2005 Osteopontin is overexpressed in human papillary thyroid carcinomas and enhances thyroid carcinoma cell invasiveness. $J$ Clin Endocrinol Metab 90 5270-5278.

Hamatani K, Eguchi H, Ito R, Mukai M, Takahashi K, Taga M, Imai K, Cologne J, Soda M, Arihiro K, et al. 2008 RET/PTC rearrangements preferentially occurred in papillary thyroid cancer among atomic bomb survivors exposed to high radiation dose. Cancer Res 68 7176-7182.

Hanahan D \& Weinberg RA 2000 The hallmarks of cancer. Cell 100 57-70.

Hemmer S, Wasenius VM, Knuutila S, Franssila K \& Joensuu H 1999 DNA copy number changes in thyroid carcinoma. Am J Pathol 154 1539-1547.

Hemmer S, Wasenius VM, Knuutila S, Joensuu H \& Franssila K 1998 Comparison of benign and malignant follicular thyroid tumours by comparative genomic hybridization. $\mathrm{Br}$ J Cancer 78 1012-1017.

Herrmann MA, Hay ID, Bartelt DH, Jr., Ritland SR, Dahl RJ, Grant CS \& Jenkins RB 1991 Cytogenetic and molecular genetic studies of follicular and papillary thyroid cancers. J Clin Invest 88 1596-1604.

Hochberg Y \& Benjamini Y 1990 More powerful procedures for multiple significance testing. Stat Med 9 811-818.

Jazdzewski K, Murray EL, Franssila K, Jarzab B, Schoenberg DR \& de la Chapelle A 2008 Common SNP in pre-miR-146a decreases mature miR expression and predisposes to papillary thyroid carcinoma. Proc Natl Acad Sci U S A 105 7269-7274. 
Jenkins RB, Hay ID, Herath JF, Schultz CG, Spurbeck JL, Grant CS, Goellner JR \& Dewald GW 1990 Frequent occurrence of cytogenetic abnormalities in sporadic nonmedullary thyroid carcinoma. Cancer 66 1213-1220.

Kallioniemi OP, Kallioniemi A, Sudar D, Rutovitz D, Gray JW, Waldman F \& Pinkel D 1993 Comparative genomic hybridization: a rapid new method for detecting and mapping DNA amplification in tumors. Semin Cancer Biol 4 41-46.

Kimura ET, Nikiforova MN, Zhu Z, Knauf JA, Nikiforov YE \& Fagin JA 2003 High prevalence of BRAF mutations in thyroid cancer: genetic evidence for constitutive activation of the RET/PTC-RAS-BRAF signaling pathway in papillary thyroid carcinoma. Cancer Res 63 1454-1457.

Kitamura Y, Shimizu K, Tanaka S, Ito K \& Emi M 2000 Association of allelic loss on 1q, 4p, 7q, $9 p, 9 q$, and $16 q$ with postoperative death in papillary thyroid carcinoma. Clin Cancer Res 6 1819-1825.

Klugbauer S, Demidchik EP, Lengfelder E \& Rabes HM 1998 Detection of a novel type of RET rearrangement (PTC5) in thyroid carcinomas after Chernobyl and analysis of the involved RET-fused gene RFG5. Cancer Res 58 198-203.

Klugbauer S, Lengfelder E, Demidchik EP \& Rabes HM 1995 High prevalence of RET rearrangement in thyroid tumors of children from Belarus after the Chernobyl reactor accident. Oncogene 11 2459-2467.

Klugbauer S \& Rabes HM 1999 The transcription coactivator HTIF1 and a related protein are fused to the RET receptor tyrosine kinase in childhood papillary thyroid carcinomas. Oncogene 18 4388-4393.

Kondo T, Ezzat S \& Asa SL 2006 Pathogenetic mechanisms in thyroid follicular-cell neoplasia. Nat Rev Cancer 6 292-306. 
Kroll TG, Sarraf P, Pecciarini L, Chen CJ, Mueller E, Spiegelman BM \& Fletcher JA 2000 PAX8PPARgamma1 fusion oncogene in human thyroid carcinoma [corrected]. Science 289 1357-1360.

Lee JJ, Au AY, Foukakis T, Barbaro M, Kiss N, Clifton-Bligh R, Staaf J, Borg A, Delbridge L, Robinson BG, et al. 2008 Array-CGH identifies cyclin D1 and UBCH10 amplicons in anaplastic thyroid carcinoma. Endocr Relat Cancer 15 801-815.

Lee JJ, Foukakis T, Hashemi J, Grimelius L, Heldin NE, Wallin G, Rudduck C, Lui WO, Hoog A \& Larsson C 2007 Molecular cytogenetic profiles of novel and established human anaplastic thyroid carcinoma models. Thyroid 17 289-301.

Lemoine NR, Mayall ES, Wyllie FS, Williams ED, Goyns M, Stringer B \& Wynford-Thomas D 1989 High frequency of ras oncogene activation in all stages of human thyroid tumorigenesis. Oncogene 4 159-164.

Lima J, Trovisco V, Soares P, Maximo V, Magalhaes J, Salvatore G, Santoro M, Bogdanova T, Tronko M, Abrosimov A, et al. 2004 BRAF mutations are not a major event in postChernobyl childhood thyroid carcinomas. J Clin Endocrinol Metab 89 4267-4271.

Lu CM, Kwan J, Baumgartner A, Weier JF, Wang M, Escudero T, Munne S, Zitzelsberger HF \& Weier HU 2009 DNA probe pooling for rapid delineation of chromosomal breakpoints. J Histochem Cytochem 57 587-597.

Manenti G, Pilotti S, Re FC, Della Porta G \& Pierotti MA 1994 Selective activation of ras oncogenes in follicular and undifferentiated thyroid carcinomas. Eur J Cancer 30A 987-993.

Mardis ER 2008 Next-generation DNA sequencing methods. Annu Rev Genomics Hum Genet 9 387-402. 
Mark J, Ekedahl C, Dahlenfors R \& Westermark B 1987 Cytogenetical observations in five human anaplastic thyroid carcinomas. Hereditas 107 163-174.

Marques AR, Espadinha C, Catarino AL, Moniz S, Pereira T, Sobrinho LG \& Leite V 2002 Expression of PAX8-PPAR gamma 1 rearrangements in both follicular thyroid carcinomas and adenomas. J Clin Endocrinol Metab 87 3947-3952.

Mitelman F 2000 Recurrent chromosome aberrations in cancer. Mutat Res 462 247-253.

Miura D, Wada N, Chin K, Magrane GG, Wong M, Duh QY \& Clark OH 2003 Anaplastic thyroid cancer: cytogenetic patterns by comparative genomic hybridization. Thyroid $13283-290$.

Musholt PB, Musholt TJ, Morgenstern SC, Worm K, Sheu SY \& Schmid KW 2008 Follicular histotypes of oncocytic thyroid carcinomas do not carry mutations of the BRAF hotspot. World J Surg 32 722-728.

Nakata T, Kitamura Y, Shimizu K, Tanaka S, Fujimori M, Yokoyama S, Ito K \& Emi M 1999 Fusion of a novel gene, ELKS, to RET due to translocation t(10;12)(q11;p13) in a papillary thyroid carcinoma. Genes Chromosomes Cancer 25 97-103.

Namba H, Rubin SA \& Fagin JA 1990 Point mutations of ras oncogenes are an early event in thyroid tumorigenesis. Mol Endocrinol 4 1474-1479.

Nappi TC, Salerno P, Zitzelsberger H, Carlomagno F, Salvatore G \& Santoro M 2009 Identification of Polo-like kinase 1 as a potential therapeutic target in anaplastic thyroid carcinoma. Cancer Res 69 1916-1923.

Nikiforov YE 2002 RET/PTC rearrangement in thyroid tumors. Endocr Pathol 13 3-16.

Nikiforova MN, Ciampi R, Salvatore G, Santoro M, Gandhi M, Knauf JA, Thomas GA, Jeremiah S, Bogdanova TI, Tronko MD, et al. 2004 Low prevalence of BRAF mutations in 
radiation-induced thyroid tumors in contrast to sporadic papillary carcinomas. Cancer Lett 209 1-6.

Nikiforova MN, Lynch RA, Biddinger PW, Alexander EK, Dorn GW, 2nd, Tallini G, Kroll TG \& Nikiforov YE 2003 RAS point mutations and PAX8-PPAR gamma rearrangement in thyroid tumors: evidence for distinct molecular pathways in thyroid follicular carcinoma. J Clin Endocrinol Metab 88 2318-2326.

Parente F, Gaudray P, Carle GF \& Turc-Carel C 1997 Experimental assessment of the detection limit of genomic amplification by comparative genomic hybridization CGH. Cytogenet Cell Genet 78 65-68.

Pierotti MA, Bongarzone I, Borello MG, Greco A, Pilotti S \& Sozzi G 1996 Cytogenetics and molecular genetics of carcinomas arising from thyroid epithelial follicular cells. Genes Chromosomes Cancer 16 1-14.

Pierotti MA, Santoro M, Jenkins RB, Sozzi G, Bongarzone I, Grieco M, Monzini N, Miozzo M, Herrmann MA, Fusco A, et al. 1992 Characterization of an inversion on the long arm of chromosome 10 juxtaposing D10S170 and RET and creating the oncogenic sequence RET/PTC. Proc Natl Acad Sci U S A 89 1616-1620.

Pinkel D, Segraves R, Sudar D, Clark S, Poole I, Kowbel D, Collins C, Kuo WL, Chen C, Zhai Y, et al. 1998 High resolution analysis of DNA copy number variation using comparative genomic hybridization to microarrays. Nat Genet 20 207-211.

Port M, Boltze C, Wang Y, Roper B, Meineke V \& Abend M 2007 A radiation-induced gene signature distinguishes post-Chernobyl from sporadic papillary thyroid cancers. Radiat Res 168 639-649.

Powell N, Jeremiah S, Morishita M, Dudley E, Bethel J, Bogdanova T, Tronko M \& Thomas G 2005 Frequency of BRAF T1796A mutation in papillary thyroid carcinoma relates to age of patient at diagnosis and not to radiation exposure. J Pathol 205 558-564. 
Rhoden KJ, Unger K, Salvatore G, Yilmaz Y, Vovk V, Chiappetta G, Qumsiyeh MB, Rothstein $\mathrm{JL}$, Fusco A, Santoro M, et al. 2006 RET/papillary thyroid cancer rearrangement in nonneoplastic thyrocytes: follicular cells of Hashimoto's thyroiditis share low-level recombination events with a subset of papillary carcinoma. J Clin Endocrinol Metab 91 2414-2423.

Richter H, Braselmann H, Hieber L, Thomas G, Bogdanova T, Tronko N \& Zitzelsberger H 2004 Chromosomal imbalances in post-chernobyl thyroid tumors. Thyroid 14 10611064.

Ringel MD, Hayre N, Saito J, Saunier B, Schuppert F, Burch H, Bernet V, Burman KD, Kohn LD \& Saji M 2001 Overexpression and overactivation of Akt in thyroid carcinoma. Cancer Res 61 6105-6111.

Rippe V, Drieschner N, Meiboom M, Murua Escobar H, Bonk U, Belge G \& Bullerdiek J 2003 Identification of a gene rearranged by 2 p21 aberrations in thyroid adenomas. Oncogene 22 6111-6114.

Rodrigues RF, Roque L, Krug T \& Leite V 2007 Poorly differentiated and anaplastic thyroid carcinomas: chromosomal and oligo-array profile of five new cell lines. $\mathrm{Br} J$ Cancer 96 1237-1245.

Roque L, Castedo S, Gomes P, Soares P, Clode A \& Soares J 1993 Cytogenetic findings in 18 follicular thyroid adenomas. Cancer Genet Cytogenet 67 1-6.

Roque L, Nunes VM, Ribeiro C, Martins C \& Soares J 2001 Karyotypic characterization of papillary thyroid carcinomas. Cancer 92 2529-2538.

Roque L, Rodrigues R, Pinto A, Moura-Nunes V \& Soares J 2003 Chromosome imbalances in thyroid follicular neoplasms: a comparison between follicular adenomas and carcinomas. Genes Chromosomes Cancer 36 292-302. 
Sadetzki S, Calderon-Margalit R, Modan B, Srivastava S \& Tuttle RM 2004 Ret/PTC activation in benign and malignant thyroid tumors arising in a population exposed to low-dose external-beam irradiation in childhood. J Clin Endocrinol Metab 89 2281-2289.

Said S, Schlumberger M \& Suarez HG 1994 Oncogenes and anti-oncogenes in human epithelial thyroid tumors. J Endocrinol Invest 17 371-379.

Salassidis K, Bruch J, Zitzelsberger H, Lengfelder E, Kellerer AM \& Bauchinger M 2000 Translocation $t(10 ; 14)(q 11.2: q 22.1)$ fusing the kinetin to the RET gene creates a novel rearranged form (PTC8) of the RET proto-oncogene in radiation-induced childhood papillary thyroid carcinoma. Cancer Res 60 2786-2789.

Salvatore G, Nappi TC, Salerno P, Jiang Y, Garbi C, Ugolini C, Miccoli P, Basolo F, Castellone MD, Cirafici AM, et al. 2007 A cell proliferation and chromosomal instability signature in anaplastic thyroid carcinoma. Cancer Res 67 10148-10158.

Santoro M, Carlomagno F, Hay ID, Herrmann MA, Grieco M, Melillo R, Pierotti MA, Bongarzone I, Della Porta G, Berger N, et al. 1992 Ret oncogene activation in human thyroid neoplasms is restricted to the papillary cancer subtype. J Clin Invest $\mathbf{8 9}$ 1517-1522.

Santoro M, Melillo RM \& Fusco A 2006 RET/PTC activation in papillary thyroid carcinoma: European Journal of Endocrinology Prize Lecture. Eur J Endocrinol 155 645-653.

Schrock E, Veldman T, Padilla-Nash H, Ning Y, Spurbeck J, Jalal S, Shaffer LG, Papenhausen P, Kozma C, Phelan MC, et al. 1997 Spectral karyotyping refines cytogenetic diagnostics of constitutional chromosomal abnormalities. Hum Genet 101 255-262.

Singh B, Lim D, Cigudosa JC, Ghossein R, Shaha AR, Poluri A, Wreesmann VB, Tuttle M, Shah JP \& Rao PH 2000 Screening for genetic aberrations in papillary thyroid cancer by using comparative genomic hybridization. Surgery 128 888-893;discussion 893-884. 
Solinas-Toldo S, Lampel S, Stilgenbauer S, Nickolenko J, Benner A, Dohner H, Cremer T \& Lichter P 1997 Matrix-based comparative genomic hybridization: biochips to screen for genomic imbalances. Genes Chromosomes Cancer 20 399-407.

Speicher MR, Gwyn Ballard S \& Ward DC 1996 Karyotyping human chromosomes by combinatorial multi-fluor FISH. Nat Genet 12 368-375.

Szuhai K, Bezrookove V, Wiegant J, Vrolijk J, Dirks RW, Rosenberg C, Raap AK \& Tanke HJ 2000 Simultaneous molecular karyotyping and mapping of viral DNA integration sites by 25-color COBRA-FISH. Genes Chromosomes Cancer 28 92-97.

Teixeira MR 2006 Recurrent fusion oncogenes in carcinomas. Crit Rev Oncog 12 257-271.

Thomas GA, Bunnell H, Cook HA, Williams ED, Nerovnya A, Cherstvoy ED, Tronko ND, Bogdanova TI, Chiappetta G, Viglietto G, et al. 1999 High prevalence of RET/PTC rearrangements in Ukrainian and Belarussian post-Chernobyl thyroid papillary carcinomas: a strong correlation between RET/PTC3 and the solid-follicular variant. J Clin Endocrinol Metab 84 4232-4238.

Tuttle RM, Lukes Y, Onstad L, Lushnikov E, Abrosimov A, Troshin V, Tsyb A, Davis S, Kopecky KJ \& Francis G 2008 ret/PTC activation is not associated with individual radiation dose estimates in a pilot study of neoplastic thyroid nodules arising in Russian children and adults exposed to Chernobyl fallout. Thyroid 18 839-846.

Unger K, Malisch E, Thomas G, Braselmann H, Walch A, Jackl G, Lewis $P$, Lengfelder $E$, Bogdanova T, Wienberg J, et al. 2008 Array CGH demonstrates characteristic aberration signatures in human papillary thyroid carcinomas governed by RET/PTC. Oncogene 27 4592-4602.

Unger K, Zitzelsberger $\mathrm{H}$, Salvatore G, Santoro M, Bogdanova T, Braselmann H, Kastner $\mathrm{P}$, Zurnadzhy L, Tronko N, Hutzler P, et al. 2004 Heterogeneity in the distribution of 
RET/PTC rearrangements within individual post-Chernobyl papillary thyroid carcinomas. J Clin Endocrinol Metab 89 4272-4279.

Unger K, Zurnadzhy L, Walch A, Mall M, Bogdanova T, Braselmann H, Hieber L, Tronko N, Hutzler P, Jeremiah S, et al. 2006 RET rearrangements in post-Chernobyl papillary thyroid carcinomas with a short latency analysed by interphase FISH. Br J Cancer 94 1472-1477.

van Beers EH, Joosse SA, Ligtenberg MJ, Fles R, Hogervorst FB, Verhoef S \& Nederlof PM 2006 A multiplex PCR predictor for aCGH success of FFPE samples. Br J Cancer 94 333-337.

van de Wiel MA \& van Wieringen WN 2007 CGHregions: Dimension Reduction for Array CGH Data with Minimal Information Loss. Cancer Inform 3 55-63.

van Wieringen WN \& van de Wiel MA 2009 Nonparametric testing for DNA copy number induced differential mRNA gene expression. Biometrics 65 19-29.

Vitagliano D, Carlomagno F, Motti ML, Viglietto G, Nikiforov YE, Nikiforova MN, Hershman JM, Ryan AJ, Fusco A, Melillo RM, et al. 2004 Regulation of p27Kip1 protein levels contributes to mitogenic effects of the RET/PTC kinase in thyroid carcinoma cells. Cancer Res 64 3823-3829.

Weier HU, Tuton TB, Ito Y, Chu LW, Lu CM, Baumgartner A, Zitzelsberger HF \& Weier JF 2006 Molecular cytogenetic characterization of chromosome 9-derived material in a human thyroid cancer cell line. Cytogenet Genome Res 114 284-291.

Wilkens L, Benten D, Tchinda J, Brabant G, Potter E, Dralle H \& von Wasielewski R 2000 Aberrations of chromosomes 5 and 8 as recurrent cytogenetic events in anaplastic carcinoma of the thyroid as detected by fluorescence in situ hybridisation and comparative genomic hybridisation. Virchows Arch 436 312-318. 
Williams ED 1966 Histogenesis of medullary carcinoma of the thyroid. J Clin Pathol 19 114118.

Wreesmann VB, Ghossein RA, Patel SG, Harris CP, Schnaser EA, Shaha AR, Tuttle RM, Shah JP, Rao PH \& Singh B 2002 Genome-wide appraisal of thyroid cancer progression. Am J Pathol 161 1549-1556.

Wu G, Mambo E, Guo Z, Hu S, Huang X, Gollin SM, Trink B, Ladenson PW, Sidransky D \& Xing M 2005 Uncommon mutation, but common amplifications, of the PIK3CA gene in thyroid tumors. J Clin Endocrinol Metab 90 4688-4693.

Yoon H, He H, Nagy R, Davuluri R, Suster S, Schoenberg D, Pellegata N \& Chapelle Ade L 2007 Identification of a novel noncoding RNA gene, NAMA, that is downregulated in papillary thyroid carcinoma with BRAF mutation and associated with growth arrest. Int J Cancer 121 767-775.

Zhu Z, Gandhi M, Nikiforova MN, Fischer AH \& Nikiforov YE 2003 Molecular profile and clinical-pathologic features of the follicular variant of papillary thyroid carcinoma. An unusually high prevalence of ras mutations. Am J Clin Pathol 120 71-77.

Zitzelsberger H, Lehmann L, Hieber L, Weier HU, Janish C, Fung J, Negele T, Spelsberg F, Lengfelder E, Demidchik EP, et al. 1999 Cytogenetic changes in radiation-induced tumors of the thyroid. Cancer Res 59 135-140. 


\section{Captions}

Figure 1: Work-flow of array comparative genomic hybridisation (array CGH)

A: DNA is isolated from either fresh/fresh-frozen tumour tissue or from formalin-fixed paraffin-embedded tissue and labelled with the fluorescence dye Cy3. Normalized (pooled) DNA from at least five healthy donors is labelled with the fluorescence dye Cy5. B: Labelled tumour and reference DNA are co-hybridised to the array slide in the presence of human cot-1 DNA. Non-specifically bound DNA is washed off the array slide.

C: The hybridised array slide is scanned using an array laser-scanner and fluorescence intensities saved in a spreadsheet file. The raw fluorescence ratios (Cy3/Cy5) for each spot on the array are averaged and normalised. The normalised log2-transformed ratios are ordered according to the position of clones on the genome and the profile divided into parts sharing the same level of copy number (segmentation e.g. using Circular Binary Segmentation (CBS) by Venkatraman et al., 2006). In the final step the segments are classified as normal, gained and lost (e.g. using the CGHcall algorithm of van de Wiel et al., 2007).

Figure 2: Finemapping of chromosomal breakpoints by FISH using large-insert clones A: Karyotype of cell line S399 after spectral karyotyping (SKY). Each chromosome is FISH labelled with a chromosome-specific mix of fluorescence dyes (left). The DAPI counterstaining image of chromosomes is transformed into a G-banding like image (middle). The fluoresence image of each chromosome is transformed into a chromosome-specific false colour. Inter-chromosome translocations are identifiable by colour-junctions in the false-colour images (white arrows).

B: Mapping of chromosomal breakpoints of rearranged chromosomes 7 and 12 . SKY images of chromosomes 7 and 12 are shown in the top panel. Middle panel: A qterminal part of chromosome 7 inserted into the q-arm of chromosome 12 . The breakpoints were narrowed down using a series of YAC and BAC clones in FISH hybridizations. YAC CEPH-953C9 binds to a region on chromosome 7 (which was inserted into marker chromosome 12) spanning the breakpoint and therefore gives three signals: one on normal chromosome 7, one proximal and one distal the breakpoint on the part of chromosome 7 (indicated by white arrows). Bottom panel: BAC clone RP11 binding 
spanning the breakpoint of chromosome $12 q$ resulting in three signals (one on normal chromosome 12, one distal and one proximal the breakpoint).

C: Genomic regions covered by breakpoint mapping FISH clones (UCSC Genome Browser). Upper panel: YAC clone CEPH-953C9 (Chr. 7q) - comprising candidate genes X, Y, Z. Lower panel: BAC clone RP11-1136G11 - comprising candidate genes: Spryd3, Igfbp6, Soat2, Acat2, Csad, Pcap, Znf740, Itgb7, Rarg).

Figure 3: Integrative bioinformatic approach as used in the Genrisk-T project For every sample data from various sources such as array $\mathrm{CGH}$, whole genome SNP genotyping, expression microarray and miRNA array are available. The complexity of each of the datasets is reduced in order to improve statistical power (e.g. taking only copy number regions into account which correlate with mRNA expression, for details see text). The reduced datasets are subsequently analysed for association with pathomorphology, molecular phenotype and clinical information. In case of a statistical significant association molecular profiles either can be directly used as biomarkers or as a starting point for the development of biomarkers. 
Table 1: DNA copy number changes in thyroid follicular-cell neoplasia

\begin{tabular}{|c|c|c|c|}
\hline Tumour type & $\begin{array}{l}\text { Number of tumours } \\
\text { analysed }\end{array}$ & $\begin{array}{l}\text { Frequent copy } \\
\text { number changes }\end{array}$ & References \\
\hline PTC & 26 tumours & $\begin{array}{l}\text { CGH } \\
\text { Gains: 1q23-qter, } 5 q \text {, } \\
7,17,21\end{array}$ & Hemmer et al., 1999 \\
\hline $\begin{array}{l}\text { PTC (classic and } \\
\text { follicular variants) } \\
\text { and PTC cell lines }\end{array}$ & $\begin{array}{l}8 \text { tumours, } 3 \text { cell } \\
\text { lines }\end{array}$ & $\begin{array}{l}\text { aCGH } \\
\text { Gains: 1, 5, 7, 11, 15, } \\
\text { 17, } 22 \\
\text { Losses: } \\
\text { chromosomes 4, 18, } \\
19\end{array}$ & Finn et al., 2007 \\
\hline PTC & $\begin{array}{l}60 \text { childhood } \\
\text { tumours }\end{array}$ & $\begin{array}{l}\text { CGH } \\
\text { Gains: 2, 7q11.2-21, } \\
\text { 13q21-22, } 21 \\
\text { Losses: } \\
\text { chromosomes 16, } \\
20 q, 22\end{array}$ & Richter et al., 2004 \\
\hline FTC & 20 tumours & $\begin{array}{l}\text { CGH } \\
\text { Gains: 1q, 14q11.2- } \\
q 22,17 q, 18 q 12.1- \\
q 21 \\
\text { Losses : 1p21-22, } \\
\text { 13q21-22, } 22\end{array}$ & Hemmer et al., 1999 \\
\hline FTC, FTA & $\begin{array}{l}12 \text { adenomas, } 20 \\
\text { carcinomas }\end{array}$ & $\begin{array}{l}\text { CGH } \\
\text { Gains : 5p11, 5p15, } \\
\text { 5q13-22, 5q21-23, } \\
\text { 7p11-12, 7q11.3- } \\
q 21,7 q 31,12 p 11, \\
12 q 11-12 \\
\text { Losses : 1p, 2p/q, } \\
3 p / q, 6 p / q, 8 p / q, 9 p, \\
11 q, 13 q, 15 q, 18 q, \\
22 q\end{array}$ & Roque et al., 2003 \\
\hline FTC, FTA & $\begin{array}{l}10 \text { fetal/embryonal } \\
\text { adenomas, } 4 \\
\text { common adenomas, } \\
4 \text { carcinomas }\end{array}$ & $\begin{array}{l}\text { CGH } \\
\text { Gains: 4, 5, 7, 9, 12, } \\
\text { 14, 16, 17 } \\
\text { Losses: } 2,11,15 q\end{array}$ & Castro et al., 2005 \\
\hline ATC & 13 tumours & $\begin{array}{l}\text { CGH } \\
\text { Gains: 7p22-pter, } \\
\text { 8q22-qter, 9q34-qter } \\
\text { Losses: } 22\end{array}$ & Hemmer et al., 1999 \\
\hline ATC & $\begin{array}{l}9 \text { tumours, } 2 \text { cell } \\
\text { lines }\end{array}$ & $\begin{array}{l}\text { CGH } \\
\text { Gains: } 3 q, 5 p, 7 p, 8 p \text {, } \\
8 q, 11 q, 20 q \\
\text { Losses : only in single } \\
\text { cases }\end{array}$ & Wilkens et al., 2000 \\
\hline
\end{tabular}




\begin{tabular}{|c|c|c|c|}
\hline ATC & 15 tumours & $\begin{array}{l}\text { CGH } \\
\text { Gains: 1p34-36, } \\
3 p 13-14,5 p 15,6 p 21 \text {, } \\
8 q 23,9 q 34,11 q 13, \\
17 q 25,19 p / q, 20 q \\
\text { Losses : 2q32-33, } \\
4 q 11-13,5 q 11-31, \\
6 q 21,8 p, 13 q 21-31\end{array}$ & $\begin{array}{l}\text { Wreesmann et al., } \\
2002\end{array}$ \\
\hline ATC & $\begin{array}{l}10 \text { tumours, } 1 \text { cell } \\
\text { line }\end{array}$ & $\begin{array}{l}\text { CGH } \\
\text { Gains: 1q21-qter, } \\
\text { 7p21.3-pter, } 20 \text { and } \\
\text { CNA in single cases } \\
\text { Losses: } 3 p 12.2-21.3 \\
\text { and CNA in single } \\
\text { cases only }\end{array}$ & Miura et al., 2003 \\
\hline ATC & 7 tumours & $\begin{array}{l}\text { CGH } \\
\text { Gains: } 3 q, 5 p, 20 p / q \\
\text { and CNA in single } \\
\text { cases } \\
\text { Losses: } X p, 7 q 31\end{array}$ & $\begin{array}{l}\text { Rodrigues et al., } \\
2004\end{array}$ \\
\hline ATC & $\begin{array}{l}28 \text { tumours, } 9 \text { cell } \\
\text { lines }\end{array}$ & $\begin{array}{l}\text { Array CGH } \\
\text { Gains: } 1 q 21,6 p 22- \\
q 21,7 q 11.22-q 11.23, \\
11 q 13,12 q 13, \\
16 p 11.2,17 q 21, \\
19 p 13,19 q 13.1- \\
q 13.2,20 q 11.2, \\
20 q 13.12,22 q 11.21 \\
22 q 13.1 \\
\text { Losses }: 4 q 12-q 13.1, \\
4 q 28.3,13 q 21.2- \\
q 21.31\end{array}$ & Lee et al., 2008 \\
\hline
\end{tabular}

1 : array-CGH $(\mathrm{aCGH})$ or conventional CGH (CGH) 
A

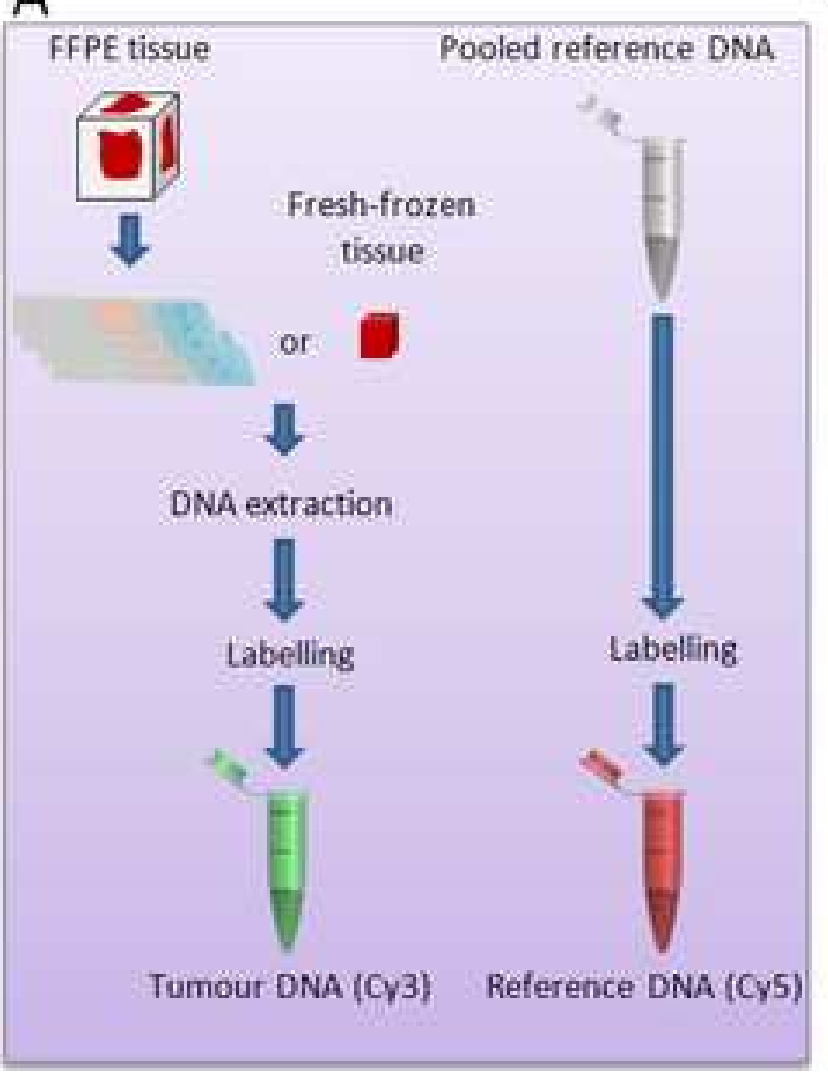

B

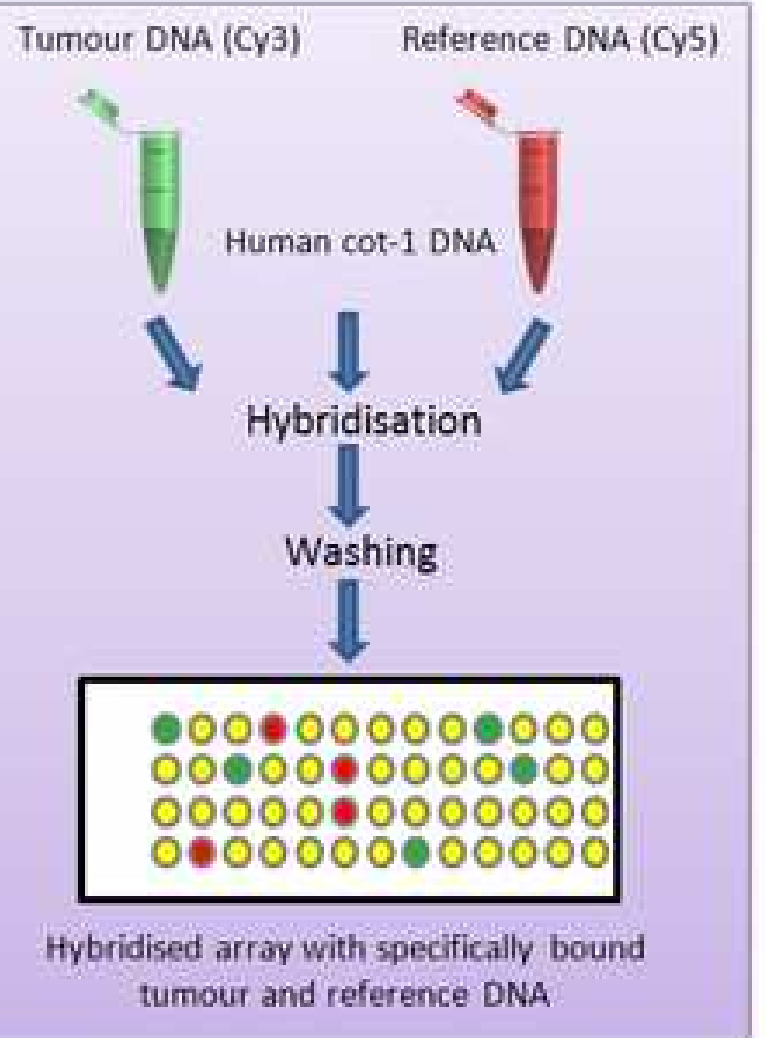

C

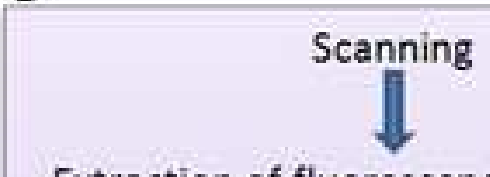

Extraction of fluorescence intensities/ Generation of raw ratios

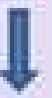

Normalisation

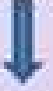

Segmentation

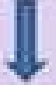

Calling of copy number gains and losses

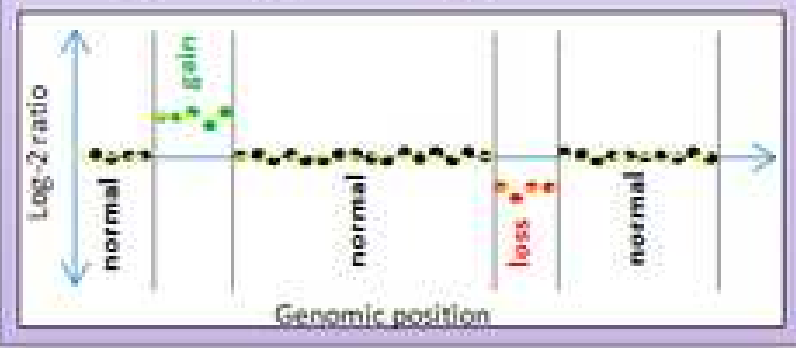


A

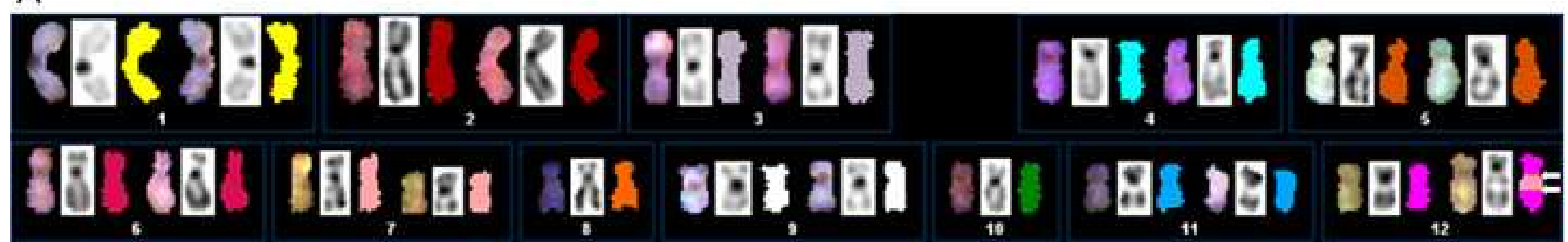

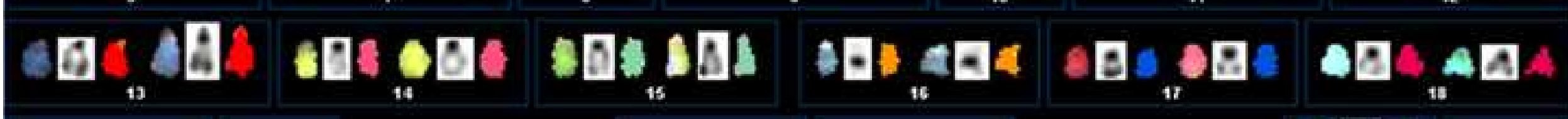
$20 \div 80 \cdot 0$ CD*

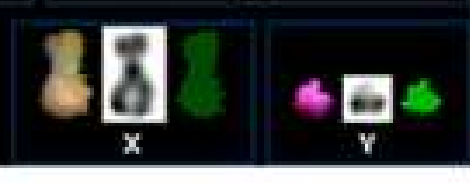
B

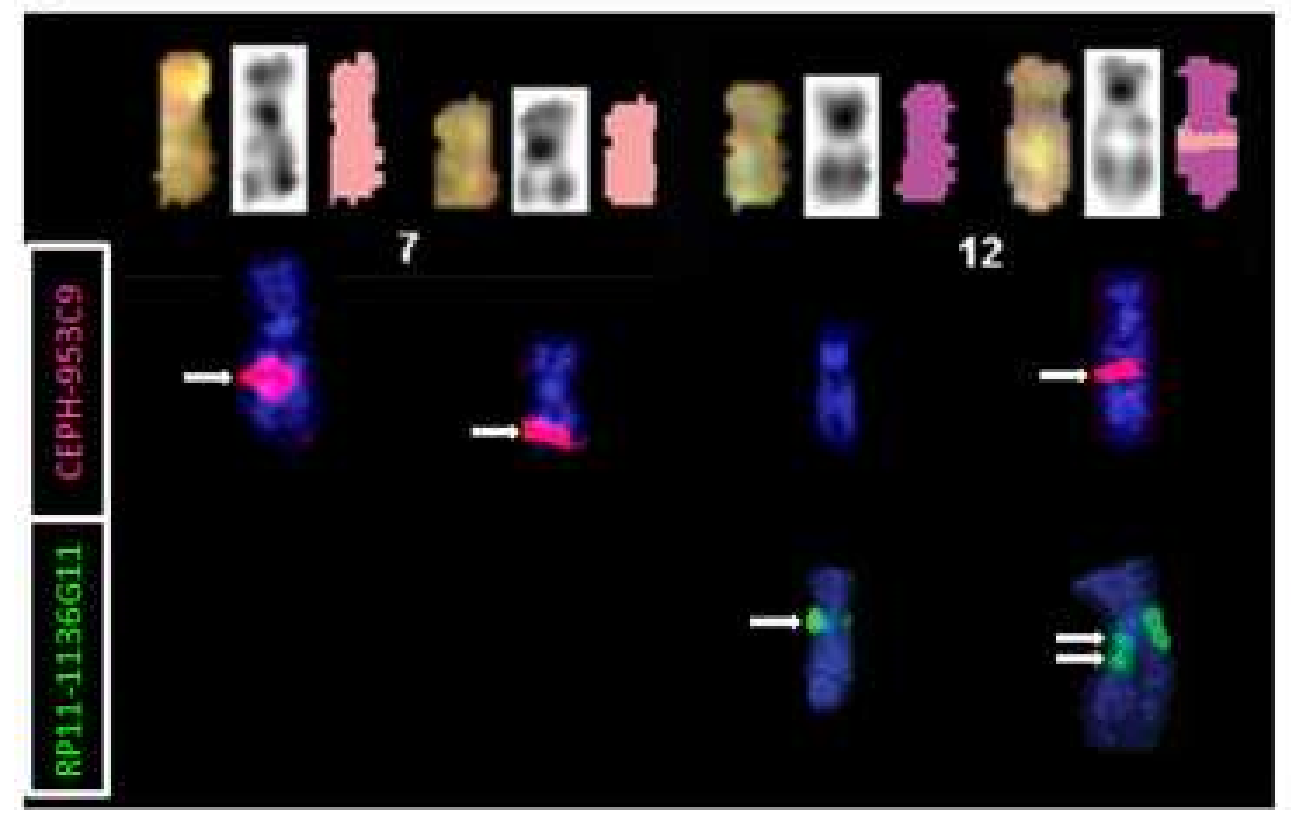
C

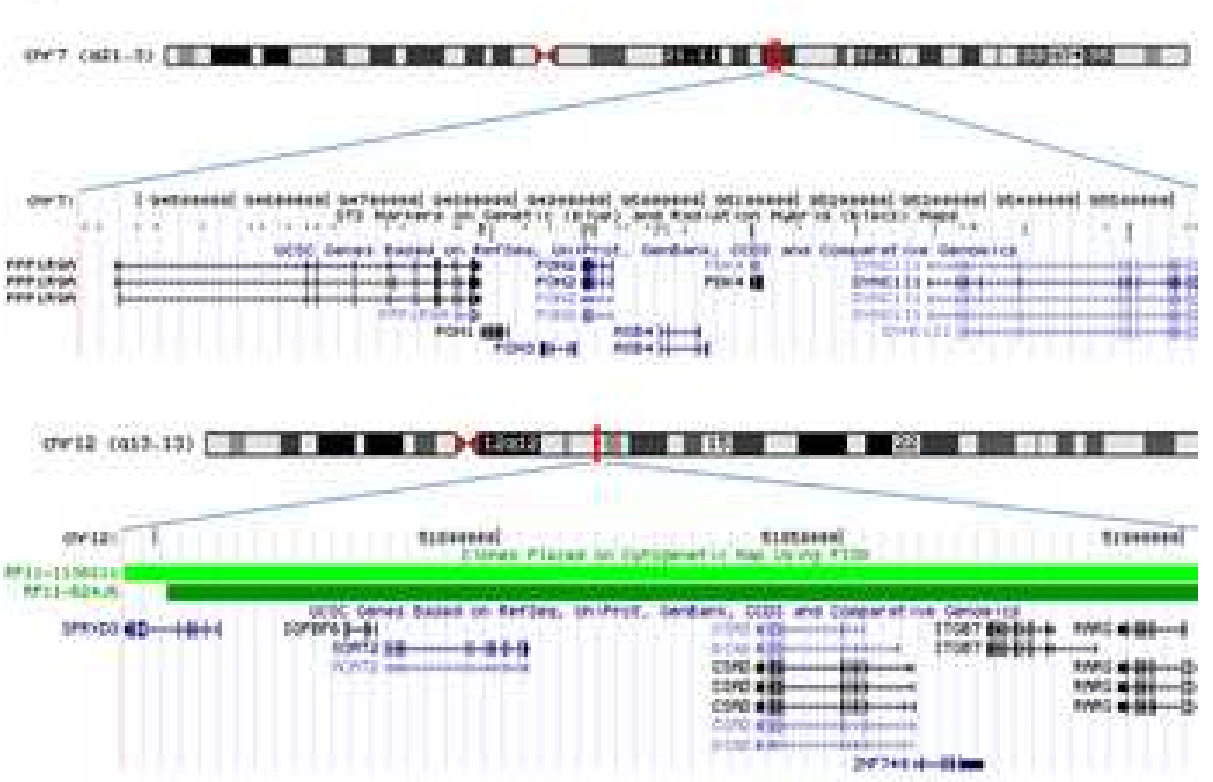



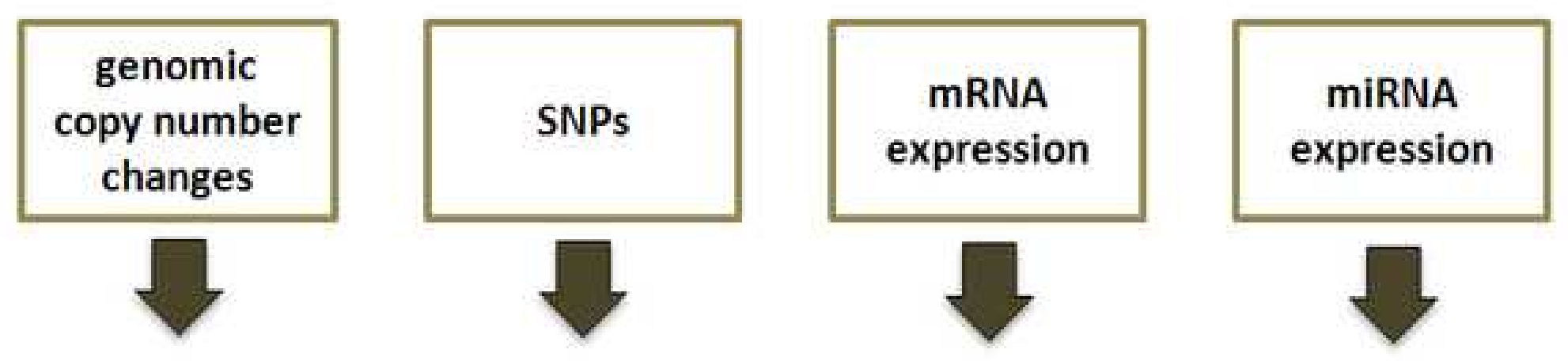

reduction of data complexity

\section{reduced data set}

$$
\text { Association with }
$$

patho-morphology

$$
\begin{array}{|l|}
\hline \text { molecular phenotype } \\
\text { biomarker } \\
\hline
\end{array}
$$

